\title{
A ESCOLA MUDOU. QUE MUDEA FORMAÇÃO DE PROFESSORES!
}

\author{
Ilma Passos Alencastro Veiga* e Edileuza Fernandes da Silva (Org.) ${ }^{* *}$ \\ Campinas: Papirus, 2010. 144 p. ISBN: 978-85-308-0906-5
}

Responsável pela Resenha: Aquiles Santos Cerqueira***

Onde termina a vida de aluno e inicia a vida de professor? Talvez tenha chegado a hora de avançarmos na resposta a essa questão. De aprofundarmos nossa percepção da vida escolar e até mesmo da vida em sociedade, para entendermos que se trata de momentos que nada mais são que pontos de vista - a serem superados - de um único processo: a formação do indivíduo e, neste caso, dos profissionais professores. De percebermos que vivemos aprendendo e ensinando numa naturalidade tal que deixamos de perceber o aprendizado quando observamos a nossa volta, e ensinamento dos nossos posicionamentos diante do mundo, ou seja, enquanto vivemos.

É nesse espírito de aprendente/ensinante e ensinante/aprendente que saio da leitura de A Escola Mudou. Que Mude a Formação de Professores!. Obra que já no título evoca a percepção sociológica da formação docente ao imperar pelo seu alinhamento com a dinâmica social. Porém, sem propor movimentos de equação à realidade, mas apresentando atitudes de mudança e resistência às adversidades impostas ao êxito do processo educativo de discentes e docentes da formação de professores.

A título de apresentação do conjunto das reflexões presentes, registra-se que a obra explicita o que seriam os princípios da organização do trabalho pedagógico na formação de professores, seja esta inicial ou continuada, a indissociabilidade entre teoria e prática e a permanente articulação dessa formação com os espaços da prática docente da educação básica. Isso confere à obra caráter de contemporaneidade.

\footnotetext{
* Doutora (1988) e Pós-Doutora (1998) em Educação pela Universidade Estadual de Campinas, SP, Brasil. Professora Emérita e Pesquisadora Associada Senior da Universidade de Brasília. Bolsista de Produtividade em Pesquisa 1B do CNPq (ipaveiga@terra.com.br).

** Doutora em Educação pela Universidade de Brasília, Brasil (2009). Diretora de Execução de Políticas e Planos Educacionais da Secretaria de Estado de Educação do Distrito Federal (favodemel13@yahoo.com.br).

*** Doutorando em Educação na Universidade de Brasília (UnB). Mestre em Educação pela UnB (2002). Professor da Faculdade Escola Superior Paulo Martins (santoscerqueira@gmail.com).
} 
Outro aspecto dessa atualidade diz respeito à apresentação de alternativas para a formação docente que reconhecem o professor como agente social, e, nos cursos de formação, a coordenação pedagógica como espaço privilegiado da formação continuada e do desenvolvimento profissional docente, num momento em que o Ministério da Educação, refletindo a percepção da sociedade, tem posto em cheque a formação desses profissionais.

Caracterizando o atual contexto social como terreno dominado pela lógica liberal dos valores de mercado, Ilma Passos Alencastro Veiga e Cleide Maria Quevedo Quixadá Viana anunciam a fragilização docente diante desse cenário e erguem o pano de fundo dos raciocínios desenvolvidos nesta obra. E propõem como alternativa fundamental de resistência a essa suposta incomensurabilidade liberal de submissão às metas mercadológicas em que se encontra a educação a implementação de uma formação humana do profissional professor capaz de romper com a simples aceitação das condições que lhe estão impostas.

Nessa linha de consolidação da formação do docente como agente social, Lívia Feitas Fonseca Borges apresenta o currículo como campo de concretização dessa postura de resistência às pressões do contexto. $\mathrm{E}$, reconhecendo possíveis contribuições da sociedade e dos diferentes contextos sociais, propõe uma educação ancorada em estudos culturais, na qual a pesquisa e a interação constante entre a formação e a prática docente constituem-se como elementos de um contínuo formativo onde a formação inicial e a continuada se intercomunicam permanentemente, estabelecendo uma dinâmica formativa ampliadora das perspectivas sociais dos envolvidos.

Buscando a materialidade dessa proposta, Edileuza Fernandes da Silva calca suas reflexões na formação de professores desenvolvida pela Universidade de Brasília - UnB - em parceria com a Secretaria de Educação do Distrito Federal - SEDF, no curso Pedagogia Para Professores em Exercício no Início de Escolarização - PIE. Essa experiência enfrentou o desafio de estabelecer uma práxis formativa na construção de conhecimento acadêmico, ao aliar práticas profissionais e teorias pedagógicas como componentes de um contínuo formativo, que teve no diálogo sua principal marca. Deixando clara a possibilidade de ruptura com um fazer formador tecnicista.

Diante do desafio do enfrentamento do contexto social relativamente adverso já decantado nesta reflexão, Rosana César de Arruda Fernandes, coerentemente com as demais autoras desta obra, propõe o fortalecimento do coletivo na efetivação da formação continuada de professores pela coordenação pedagógica. Considerando a coordenação pedagógica o lócus próprio da organização do trabalho pedagógico, portanto, das reflexões curriculares e da participação e integração dos profissionais, apresenta-a como espaço na- 
tural de um modelo de formação continuada que possibilita aos professores o vislumbre da realidade educativa de pontos de vista dificilmente perceptíveis àqueles imersos apenas na prática docente.

Longe de encerrar o debate, Maria Antônia Tolentino nos apresenta a experiência do CRA - Centro de Referência de Alfabetização -, espaço de coordenação pedagógica dos professores do Bloco Inicial de Alfabetização - BIA -, implantado na educação básica pública da SEDF, que é apoiado pela Escola de Aperfeiçoamento dos Profissionais da Educação - EAPE -, também da SEDF. Ao se caracterizar como espaço de intercâmbio de experiências entre professores e coordenadores pedagógicos de diferentes escolas, fomentou ações de formação continuada para os professores a partir de debates de situações concretas vivenciadas por aqueles profissionais, tornando-se não apenas referência de formação continuada dos professores alfabetizadores, mas, acima de tudo, uma evidência da possibilidade de tudo o que foi apresentado nessas reflexões. Uma prova, como a experiência do PIE, de que outra formação de professores é possível.

Concluímos afirmando ser A Escola Mudou. Que Mude A Formação dos Professores! proposição contemporânea e de grande importância aos educadores e à formação de profissionais da educação. Sua relevância, entre outros aspectos, repousa na apresentação e análise de possibilidades concretas de efetivação dos debates teóricos quanto à formação dos professores e sua articulação com a prática docente na educação básica. 